\title{
Our new stethoscope in the Emergency Department: Handheld ultrasound
}

\author{
Acil serviste yeni steteskopumuz: El ultrasonu
}

\author{
Figen COŞKUN, ${ }^{1}$ Emine AKINCI, ${ }^{1}$ Mehmet Ali CEYHAN, ${ }^{2}$ Havva ŞAHİN KAVAKLI ${ }^{3}$
}

\section{BACKGROUND}

The concept of Focused Assessment with Ultrasound for Trauma (FAST), which was introduced by Rozycki et al. in 1996, has started a new era in the management of trauma patients. Today, Advanced Trauma Life Support (ATLS) suggests bedside ultrasonography (USG) evaluation of trauma patients. We aimed to investigate the usability and the reliability of handheld ultrasound (Vscan) in determining free fluid during the initial evaluation of trauma patients.

\section{METHODS}

This was a multi-center, prospective study involving multiple trauma patients who presented to three hospital emergency departments (EDs). FAST was completed using Vscan by an emergency physician and an abdominal USG was performed by a radiologist on all patients. Results of Vscan, abdominal USG and other radiological studies, if performed, were compared.

\section{RESULTS}

A total of 216 patients were included in the study. Of those, 203 had negative Vscan results, while 13 had positive results. When USG performed by a radiologist was considered as the gold standard, Vscan sensitivity for FAST was $88.9 \%$, specificity was $97.6 \%$, negative predictive value was $99.5 \%$, and positive predictive value was $61.5 \%$ in our study.

\section{CONCLUSION}

Vscan, as the smallest portable imaging device, seems to have a promising future as an indispensable gadget, equal to stethoscopes, in evaluating trauma and other critical patients.

Key Words: Emergency department; FAST; handheld ultrasound; Vscan.

\section{AMAÇ}

1996 yılında Rozycki ve arkadaşları tarafından önerilen Focused Assesment with Ultrasound for Trauma (FAST) kavramıla travma hastalarına yaklaşımda yeni bir dönem başlamıştır. Günümüzde travma hastalarında yatak başı ultrasonografi (USG) değerlendirilmesi Advanced Trauma Life Support (ATLS) içine dahil edilmiştir. Bu çalışmada, acil servise başvuran travma hastalarının ilk değerlendirilmesinde el ultrasonunun (Vscan) karıniçi serbest sıvı varlığının saptanmasında kullanılabilirliğini ve güvenilirliğini araştırmayı amaçladık.

\section{GEREÇ VE YÖNTEM}

$\mathrm{Bu}$ çalışma, çok merkezli ve prospektiftir. Üç eğitim hastanesinin acil servisine başvuran çoklu travma hastaları değerlendirildi. Acil tıp uzmanı tarafından Vscan aracılığı ile FAST ve radyoloji uzmanı tarafından karın USG'si yapıldı. Vscan sonuçları, karın USG sonuçları ve yapıldıysa diğer görüntüleme yöntemi ile karşılaştırıldı.

\section{BULGULAR}

Çalışmaya 216 hasta alınmış olup, 203 hastada Vscan ile yapılan FAST negatifken, 13 hastada pozitifti. Radyoloji uzmanı tarafindan yapılan USG altın standart olarak kabul edildiğinde, FAST'in duyarlılığg $\% 88,9$, özgüllüğü $\% 97,6$, negatif tahmini değeri 99,5, pozitif tahmini değeri ise $\% 61,5$ olarak saptand1.

\section{SONUÇ}

Taşınabilir görüntüleme cihazlarının en küçüğü olan Vscan acil serviste gerek travma hastaları gerekse kritik hasta değerlendirilmesi sırasında boynumuzda taşıyabildiğimiz steteskopumuz kadar vazgeçilmez bir araç olacaktır.

Anahtar Sözcükler: Acil servis; FAST; el ultrasonu; Vscan.
${ }^{1}$ Ankara Training and Research Hospital, Ankara; ${ }^{2}$ Ankara Numune Training and Research Hospital, Ankara; ${ }^{3}$ Ankara Atatürk Training and Research Hospital, Ankara, Turkey.
${ }^{1}$ Ankara Eğitim ve Araştırma Hastanesi, Ankara; ${ }^{2}$ Ankara Numune Eğitim ve Araştırma Hastanesi, Ankara; ${ }^{3}$ Ankara Atatürk Eğitim ve Araştırma Hastanesi, Ankara. 
When managing trauma patients, a rapid diagnosis and the most appropriate treatment are crucial. For abdominal trauma patients, computed tomography (CT) and ultrasonography (USG) are the two major diagnostic tools used to determine the need for laparotomy. Bedside applicability, speed, cost-effectiveness, and high sensitivity for determining intraabdominal free fluid make USG a tool-of-choice for the evaluation of unstable trauma patients. ${ }^{[1]}$ The concept of Focused Assessment with Ultrasound for Trauma (FAST), which was introduced by Rozycki et al. ${ }^{[2]}$ in 1996, began a new era in the management of trauma patients. Today, bedside USG FAST evaluation of trauma patients is recommended in the Advanced Trauma Life Support (ATLS) guidelines. We used Vscan as the handheld USG.

Vscan is a portable imaging device, which can be used easily in emergency departments (EDs). It weighs 320 grams and measures $13 \times 7 \times 3 \mathrm{~cm}$ and allows abdominal, cardiac and obstetric evaluation of patients. This study reports on the usability and reliability of handheld ultrasound (Vscan) in determining the existence of free intra-abdominal fluid during the initial evaluation of trauma patients in EDs by emergency physicians.

\section{MATERIALS AND METHODS}

This research was undertaken at three hospitals. The sample was selected from multiple trauma patients who presented at Ankara Training and Research Hospital, Ankara Numune Training and Research Hospital or Ankara Atatürk Training and Research Hospital EDs in Turkey, from June 1 to June 30, 2010. Only the trauma patients who were evaluated to have abdominal trauma findings and who agreed to participate were included in the study. Patients under 16 years of age, pregnant patients and those without abdominal trauma were excluded from the study.

Approval for the study was obtained from the Local Ethics Committee. All of the EDs in the participating hospitals are equipped with radiological imaging tools and X-ray equipment. Furthermore, the USG and CT devices are within easy reach in the ED. All the emergency physicians who used Vscan during the study underwent a 4-hour didactic training about the properties of the device and FAST techniques, as well as 4 hours of manikin and real-time patient evaluation training prior to the study.

All patients were evaluated according to the ATLS principles. FAST was completed using Vscan by an emergency physician. All patients were then evaluated by a radiologist in the radiology examination room. The ultrasound machines used by the radiologists were Toshiba SSA660A at Ankara Training and Research Hospital, Toshiba Nemio 10 at Ankara Numune Train- ing and Research Hospital and Siemens Sonoline G4 at Ankara Atatürk Training and Research Hospital. The time between two evaluations averaged 10 minutes. All of those EDs see 500 to 600 patients per day on average. Even though the numbers vary between the weekdays and weekends, the average number of trauma patients seen daily in each of those EDs is around 100. Radiologists were residents with one or more years of practical experience and an average of 20 abdominal USG examinations of trauma patients per day. All participating radiologists average six ED shifts per month. The results of the Vscan, abdominal USG and other radiological studies, if performed, were compared. The demographic information, physical examination and FAST findings were recorded in standardized forms.

Vscan is a pocket-sized visualization tool providing black and white anatomic and color-coded blood flow images in real-time. The images are generated based on ultrasound technology. Harmonic imaging, B-mode and color-flow are the standard modes of Vscan. The device has a battery that provides one-hour uninterrupted scanning. Vscan allows longitudinal measurement and can scan to a maximum depth of $24 \mathrm{~cm}$ (Fig. 1).

\section{Statistical Analysis}

Kappa statistics were used in the comparison of the FAST examination and radiology results. Pearson's chi-square and Fisher's exact tests were used for the analysis of the differences. The area under the curve (AUC) value and its confidence interval (CI) were calculated for the performance evaluation of FAST diagnosis. The Mann-Whitney U test was used for the analysis of the time differences between positive and negative FAST outcomes and Vscan times. Calculated $\mathrm{p}$ values less than 0.05 were considered as statistically significant. All data were evaluated using MedCalc 11.2.1 software.

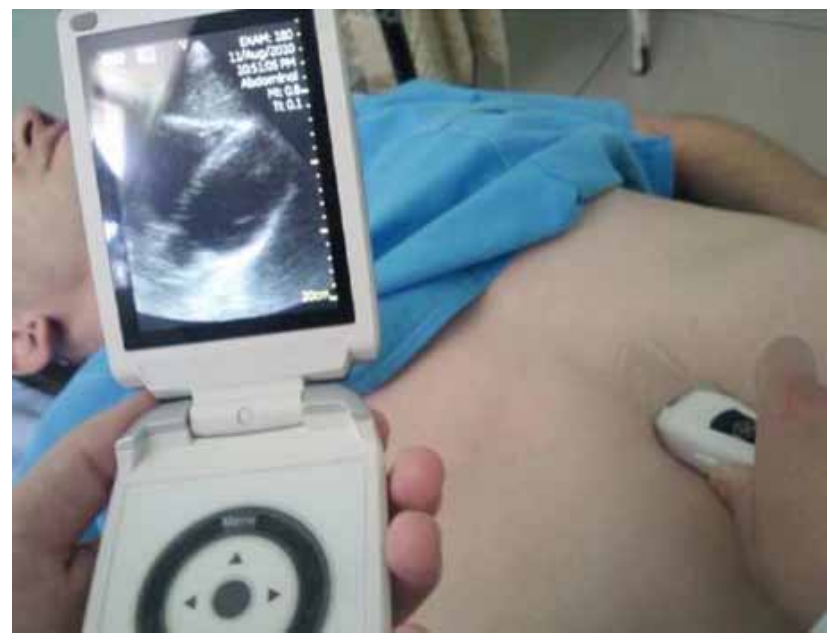

Fig. 1. Vscan picture.

(Color figure can be viewed in the online issue, which is available at www.tjtes.org) 


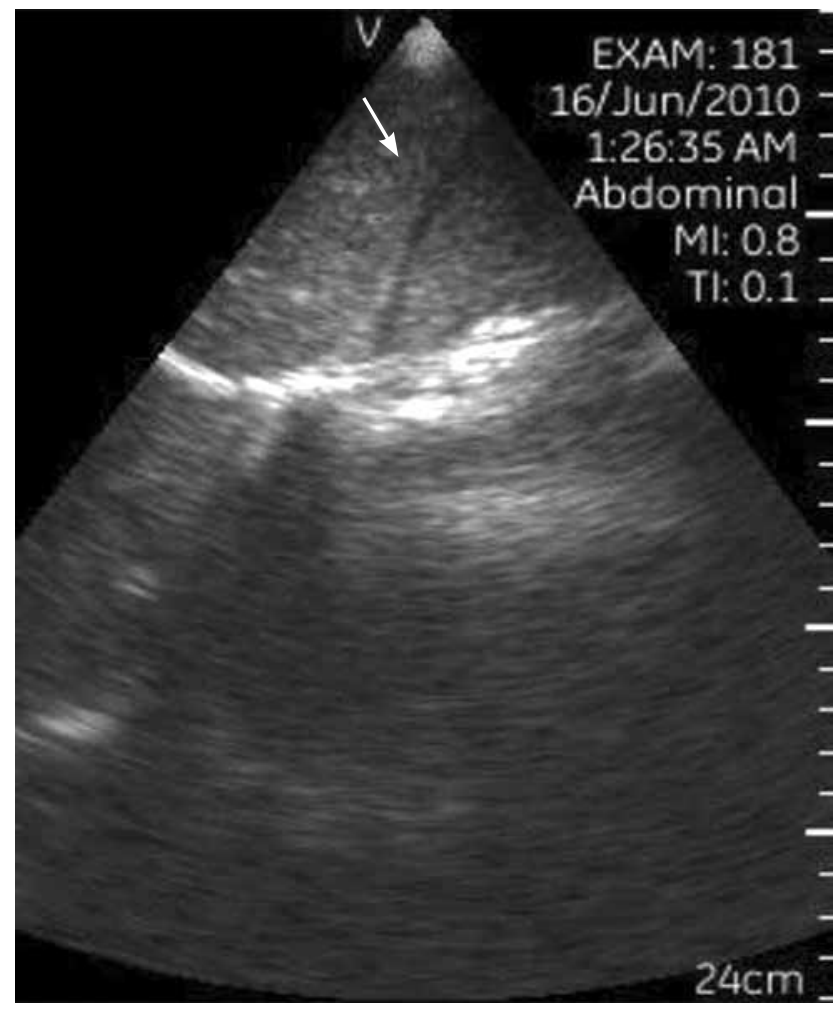

Fig. 2. Free fluid (black stripe, indicated by red arrows) within Morison's pouch.

\section{RESULTS}

A total of 216 patients were included in the study, of which $110(51 \%)$ had been involved in a motor vehicle accident, $43(20 \%)$ had fallen from height, 41 (19\%) had been the victim of assault, and $22(10 \%)$ had work-related injuries. Two hundred and three patients had negative Vscan results, while 13 had positive results (Table 1) (Fig. 2).

The average FAST time for the emergency physicians was 2.5 minutes, and radiologists completed the FAST exam in 2 minutes. A statistically significant relevance was noted when USG performed by a radiologist was considered as the gold standard (kappa $=0.713 ; \mathrm{p}<0.001)$. FAST sensitivity was calculated as $88.9 \%$ (95 CI\%: 51.8\%-99.7\%), specificity as $97.6 \%$ (95\% CI: $94.5 \%-99.2 \%)$ and AUC value as 0.93 (95\% CI: $0.89-0.96 ; \mathrm{p}<0.001$ ). The negative predictive value for FAST was calculated as $99.5 \%$ and the positive predictive value as $61.5 \%$. Fig. 3 shows the ROC (receiver operating characteristics) analysis for the accuracy of diagnosis using FAST.

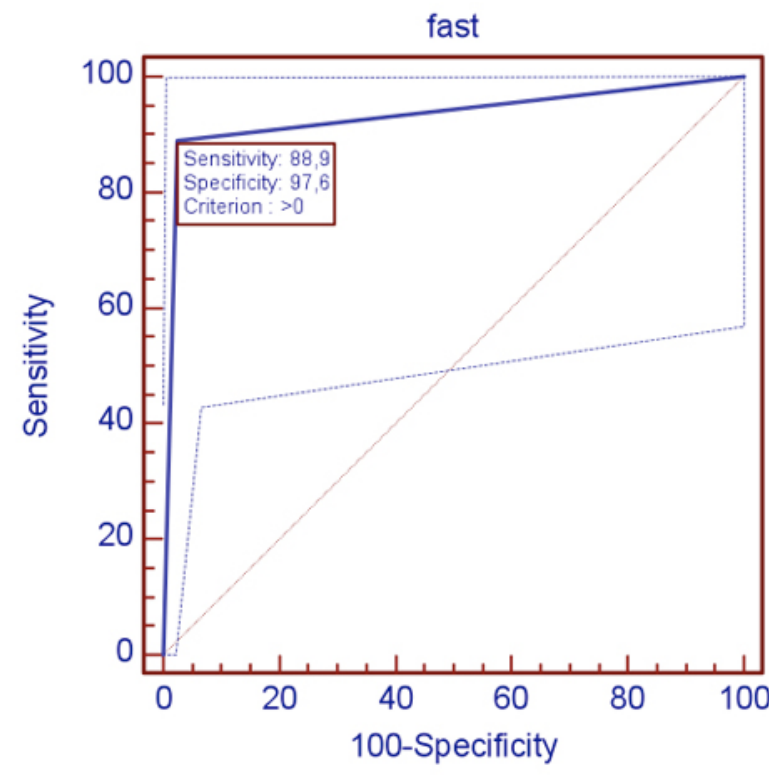

Fig. 3. Receiver Operating Characteristic (ROC) curve analysis for accuracy of diagnosis using FAST.

(Color figure can be viewed in the online issue, which is available at www.tjtes.org)

We found a statistically significant correlation between the results of FAST performed by emergency physicians using Vscan and the results of the abdominal USG performed by radiologists $(\mathrm{p}<0.001)$ (Table 2$)$.

Five patients in the study had positive Vscan FAST results but negative USG results. The abdominal CT proved to be negative for intraabdominal injuries in two of those patients and they were discharged following an observation period. Two patients had intraabdominal solid organ injuries detected by abdominal CT. They were monitored conservatively and were discharged after 6.8 days without the need for surgical intervention. The last of the five patients were unstable upon presentation and underwent emergency splenectomy for ruptured spleen. One patient had a negative Vscan FAST result but a positive USG. An abdominal CT was performed to finalize the diagnosis and the result was negative, confirming the Vscan result. This patient was discharged following observation for 24 hours (Table 2).

\section{DISCUSSION}

The development of diagnostic ultrasound devices accelerated in the ' 90 s and portable, laptop-like small and light devices began to be produced. These

Table 1. Correlation between FAST examination results and USG examination results

\begin{tabular}{lccc}
\hline & Abdominal USG - & Abdominal USG + & Fisher's Exact Test $\mathrm{p}$ value \\
\hline FAST - & $202(97.6 \%)$ & $1(11.1 \%)$ & $<0.001$ \\
FAST + & $5(2.4 \%)$ & $8(88.9 \%)$ & \\
Total & $207(100 \%)$ & $9(100 \%)$ & \\
\hline
\end{tabular}


Table 2. Crosstabs FAST with Vscan by emergency physicians

\begin{tabular}{llccc}
\hline & & \multicolumn{2}{c}{ USG } & \\
\cline { 3 - 3 } & & Normal & Pathology & Total \\
\hline FAST negative & Count & 202 & 1 & 203 \\
& \% within FAST & $99.5 \%$ & $.5 \%$ & $100.0 \%$ \\
FAST positive & \% within & $97.6 \%$ & $11.1 \%$ & $94.0 \%$ \\
& Count & 5 & 8 & 13 \\
Total & \% within FAST & $38.5 \%$ & $61.5 \%$ & $100.0 \%$ \\
& \% within & $2.4 \%$ & $88.9 \%$ & $6.0 \%$ \\
& & 207 & 9 & 216 \\
& & $95.8 \%$ & $4.2 \%$ & $100.0 \%$ \\
& & $100.0 \%$ & $100.0 \%$ & $100.0 \%$ \\
\hline
\end{tabular}

*USG performed by a radiologist using FAST.

portable ultrasound devices allowed users to perform FAST, echocardiography, obstetric USG, and Doppler evaluations on patients. ${ }^{[3-5]}$ These technological advancements allowed medical practitioners other than radiologists, as well as nurses and paramedics, to perform in- and out-of-hospital (ambulance, helicopter, military applications, disaster triage, etc.) USG exams. ${ }^{[6,7]}$ The current literature reveals a large number of articles on the feasibility and areas of use of portable ultrasound devices including the bedside USG evaluation of trauma patients in an ED.

Trauma is the leading cause of mortality in young people worldwide. ${ }^{[8]}$ The majority of trauma-related deaths occur during the first hour following the trauma, which is known as the "Golden Hour". In order to reduce deaths during the golden hour, rapid and accurate interventions during the pre-hospital, triage and early ED phases should be provided. ${ }^{[8]}$ Abdominal injuries are the third deadliest injuries following head and chest trauma. ${ }^{[9]}$ USG has proven useful in the management of abdominal trauma patients over the past 30 years. The introduction of FAST in the ' $90 \mathrm{~s}$ has made USG a popular tool, especially in the ED. ${ }^{[9,10]}$ In Turkey, in the ED, the FAST examination is administered to trauma patients simultaneously with the ATLS care. There is ample support in the literature for use of FAST in trauma patients. Smith et al., ${ }^{[1]]}$ in 2010, stated that abdominal assessment with FAST was a time-saving procedure for definitive treatment and other advanced examinations in developing countries. In another study of 500 patients, McGahan et al., ${ }^{[12]}$ in 1997, compared USG findings with laparotomy and abdominal CT in hemoperitoneum and organ injuries. They found a USG sensitivity of $63 \%$ and specificity of $95 \%$ in detecting these particular injuries. Nelson et al., ${ }^{[3,13]}$ in their 2008 study, summarized studies on outof-hospital uses of portable USG devices. They determined that portable USG devices are not only useful for FAST, but can also be successfully used to determine cardiac activity and pericardial tamponade by emergency medical services (EMS) providers in their
ACLS algorithms, in Germany and Italy. As the smallest portable imaging device, Vscan can image cardiac activity as well as abdominal structures. We believe that Vscan will prove useful not only in performing FAST and abdominal evaluations in the EDs, but also in evaluating and observing critical patients.

We have not found any publication related to Vscan in the literature; however, this device has been made available only recently. Vscan is a handheld device and enables personalized use at the point of care. It can be used by physicians, as well as possibly by nurses, paramedics or even medical students under the supervision of a physician. It can be integrated easily into physical examinations, allowing physicians to add a visual inspection of the body. The clinical applications of Vscan include cardiac, abdominal, urinary, bladder, obstetrics and gynecology, thoracic/pleural fluid, and motion detection.

In conclusion, Vscan, as the smallest portable imaging device, seems to have a promising future as an indispensable gadget which, like the stethoscope, could be used by all medical practitioners and assist in the evaluation of trauma and other critical patients in the ED.

\section{Disclosure}

The authors declare that they have no actual or potential competing financial interests.

\section{REFERENCES}

1. Rose JS. Ultrasound in abdominal trauma. Emerg Med Clin N Am 2004;22:581-99.

2. Rozycki GS, Ochsner MG, Schmidt JA, Frankel HL, Davis TP, Wang D, et al. A prospective study of surgeon-performed ultrasound as the primary adjuvant modality for injured patient assessment. J Trauma 1995;39:492-8; discussion 498500 .

3. Nelson BP, Chason K. Use of ultrasound by emergency medical services: a review. Int J Emerg Med 2008;1:253-9.

4. Kirkpatrick AW, Sirois M, Laupland KB, Goldstein L, Brown DR, Simons RK, et al. Prospective evaluation of hand-held focused abdominal sonography for trauma (FAST) in blunt 
abdominal trauma. Can J Surg 2005;48:453-60.

5. Rugolotto M, Hu BS, Liang DH, Schnittger I. Rapid assessment of cardiac anatomy and function with a new hand-carried ultrasound device (OptiGo): a comparison with standard echocardiography. Eur J Echocardiogr 2001;2:262-9.

6. Lapostolle F, Petrovic T, Lenoir G, Catineau J, Galinski M, Metzger J, et al. Usefulness of hand-held ultrasound devices in out-of-hospital diagnosis performed by emergency physicians. Am J Emerg Med 2006;24:237-42.

7. Walcher F, Weinlich M, Conrad G, Schweigkofler U, Breitkreutz R, Kirschning T, et al. Prehospital ultrasound imaging improves management of abdominal trauma. Br J Surg 2006;93:238-42.

8. Davis JH, Pruitt JH, Pruitt BA Jr. History. In: Mattox KL, Feliciano DV, Moore EE, editors. Trauma. 4th ed., New York: McGraw Hill; 2000. p. 3-19.
9. Tsui CL, Fung HT, Chung KL, Kam CW. Focused abdominal sonography for trauma in the emergency department for blunt abdominal trauma. Int J Emerg Med 2008;1:183-7.

10. Chung KL, Kam CW. Emergency ultrasonography in a patient of blunt traumatic haemoperitoneum. Hong Kong Journal Emerg Med 1995;2:104-7.

11. Smith ZA, Postma N, Wood D. FAST scanning in the developing world emergency department. S Afr Med J 2010;100:105-8.

12. McGahan JP, Rose J, Coates TL, Wisner DH, Newberry P. Use of ultrasonography in the patient with acute abdominal trauma. J Ultrasound Med 1997;16:653-62

13. Heegaard W, Plummer D, Dries D, Frascone RJ, Pippert G, Steel D, et al. Ultrasound for the air medical clinician. Air Med J 2004;23:20-3. 